\title{
ANALISIS PENGARUH SIKAP TERHADAP MINAT BELI ONLINE MELALUI DROPSHIPPER PADA MEDIA E- COMMERCE
}

\author{
Nur'sakdah ${ }^{1}$, Akhmad Saufi ${ }^{2}$, Baiq Handayani Rinuastuti ${ }^{3}$ \\ 1Program Magister Manajemen, Universitas Mataram, Indonesia \\ Email : nailaazkiarahma@gmail.com \\ ${ }^{2}$ Fakultas Ekonomi dan Bisnis, Universitas Mataram, Indonesia \\ akh.saufi72@gmail.com \\ ${ }^{3}$ Fakultas Ekonomi dan Bisnis, Universitas Mataram, Indonesia \\ hrinuastuti@yahoo.com
}

ARTICLE INFO
Keywords:
Attitude, Cognitive, Affective, Conative,
Buying Interest Online, E-commerce
Kata Kunci:
Sikap, Kognitif, Afektif, Konatif, Minat Beli
Online, E-commerce
How to cite:
Nur'sakdah., Saufi, Akhmad., Rinuastuti,
Baiq Handayani., (2021). Analisis
Pengaruh Sikap Terhadap Minat Beli
Online Melalui Dropshipper Pada Media E-
Commerce. JMM UNRAM, 10(3),175-185
DOI: :
https://doi.org/10.29303/jmm.v10i3.66
4 $\quad$ : 24 Agustus 2021
Dikumpulkan : 16 Agustus 2021
Direvisi Agustus 2021
Dipublikasi

\section{ARTICLE INFO}

Attitude, Cognitive, Affective, Conative, Kata Kunci

Sikap, Kognitif, Afektif, Konatif, Minat Beli

How to cite:

Nur'sakdah., Saufi, Akhmad, Rinuastut

Baiq Handayani., (2021). Analisi

Online Melalui Dropshipper Pada Media E-

Commerce. IMM UNRAM, 10(3),175-185

DOI

https://doi.org/10.29303/jmm.v10i3.66

Direvis

: 24 Agustus 2021

\section{ABSTRACT}

This study is aims to analyze and determine the significant of the influence of the dropshipper's cognitive attitude on online buying interest, to analyze and to find out the significant of the influence of the dropshipper's affective attitude on online purchase interest, to analyze and to determine the significant of the influence of the dropshipper's conative attitude on online purchase interest in e-commerce media. This type of research is associative causality. This study uses convenience sampling method in determining the sample. The number of respondents was 80 people. The data collection method in this research is a questionnaire. The data analysis technique used in this study is multiple linear regression. The results showed that cognitive attitudes have a positive and not significant effect on online buying interest, affective attitudes have a positive and significant effect on online buying interest, conative attitudes have a positive and significant effect on online buying interest.

Tujuan penelitian ini adalah untuk mengetahui pengaruh sikap kognitif, afektif, dan konatif terhadap minat beli online melalui dropshipper pada media e-commerce. Populasi dalam penelitian ini adalah individu/masyarakat NTB yang berminat untuk berbelanja online melalui dropshiper. Teknik penentuan sampel yang digunakan pada penelitian ini adalah nonprobability sampling dengan metode convenience sampling. Dengan metode convenience sampling, responden yang berhak mengisi kuesioner tergantung sepenuhnya kepada kemudahan penelitian. Analisis yang digunakan dalam 


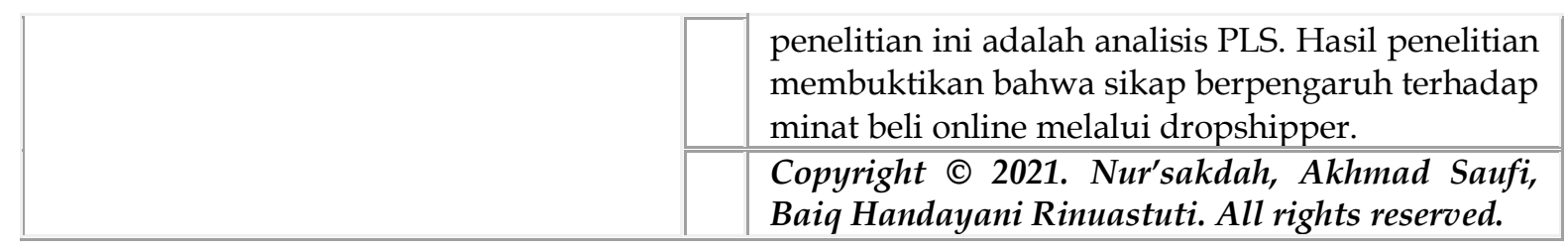

\section{PENDAHULUAN}

Pertumbuhan pesat pangsa pasar e-commerce di Indonesia memang tidak dapat diragukan lagi. Berdasarkan databoks, 2019 bahwa Indonesia memiliki nilai transaksi $e$ commerce tertinggi dibandingkan negara lain di Asia Tenggara seperti Vietnam, Thailand, Filipina, Malaysia, dan Singapura. Nilai transaksi e-commerce di Indonesia diperkirakan mencapai US\$ 21 miliar pada tahun 2019 dan diperkirakan berkali lipat menjadi US\$ 82 miliar pada tahun 2025 (Puspasari, 2019). Sebanyak 90\% dari pengguna internet berusia 1664 tahun di Indonesia pernah melakukan pembelian produk dan jasa secara online.

Menurut Kotler dan Keller (2009) minat beli merupakan perilaku yang muncul atau dirasakan konsumen sebagai respon terhadap objek yang menunjukkan keinginan konsumen untuk melakukan pembelian. Minat beli tersebut dapat dilihat dari besar kecilnya keinginan seseorang (dalam hal ini pengguna internet/konsumen online) menjadikan belanja online sebagai tujuan utama transaksi, mencari referensi informasi mengenai produk terkait, dan ketertarikan belanja online ketimbang belanja konvensional atau belanja offline.

Beberapa penelitian terdahulu yang menunjukkan hasil yang berbeda-beda seperti pada variabel sikap terhadap minat membeli. Pada penelitian Lim et al., (2016) menyatakan bahwa niat dianggap sebagai indikator sejauh mana orang bersedia mendekati perilaku tertentu dan berapa banyak upaya yang mereka coba untuk melakukan perilaku tertentu. Penelitian yang dilakukan oleh Putra \& Sudiksa (2016) menunjukkan bahwa niat beli dipengaruhi oleh sikap. Penelitian lainnya oleh Binalay (2016) juga menunjukkan bahwa sikap berpengaruh positif dan signifikan terhadap minat membeli secara online. Sreen et al., (2018) melakukan penelitian mengenai pengaruh sikap terhadap minat beli konsumen green product dan menemukan bahwa sikap memiliki pengaruh terhadap minat beli konsumen. Penelitian oleh Ansyah dan Abror (2019) juga mendukung penelitian sebelumnya dimana hasil penelitian menunjukkan bahwa sikap konsumen memiliki pengaruh positif dan signifikan terhadap minat beli konsumen Lazada di kota Padang.

Dimensi penelitian ini didasarkan pada teori struktur sikap, dimana minat pembelian merupakan bagian dari struktur sikap. Namun penelitian ini menggunakan pendekatan mengenai ketidakpuasan atas penjelasan inkonsistensi yang terjadi diantara ketiga sikap kognitif, afektif, dan konatif dalam membentuk sikap. Oleh karena itu, peneliti mengikuti pendekatan ini yang memandang perlu untuk membatasi konsep sikap pada aspek kognitif, afektif, dan konatif. Selanjutnya akan muncul minat (keinginan) pada diri pelanggan yang merupakan proses afektif (perasaan). Setelah proses operasionalisasi, dilanjutkan penentuan indikator yang dapat merefleksikan minat pembelian. Akan tetapi penelitian yang dilakukan oleh Wattimena et al., (2015) menunjukkan bahwa variabel sikap afektif tidak berpengaruh signifikan terhadap minat beli. 


\section{TINJAUAN PUSTAKA}

\subsection{Minat Beli}

Menurut Kotler (2008) minat beli adalah sesuatu yang timbul setelah menerima rangsangan dari produk yang dilihatnya, dari sana timbul ketertarikan untuk membeli agar dapat memilikinya.

Menurut Ferdinand (2006) minat beli dapat diidentifikasi melalui indikatorindikator sebagai berikut:

1. Minat transaksional, yaitu kecenderungan seseorang untuk membeli produk.

2. Minat referensial, yaitu kecenderungan seseorang untuk mereferensikan produk kepada orang lain.

3. Minat preferensial, yaitu minat yang menggambarkan perilaku seseorang yang memiliki preferensi utama pada produk tersebut. Preferensi ini hanya dapat diganti jika terjadi sesuatu dengan produk preferensinya.

4. Minat eksploratif, minat ini menggambarkan perilaku seseorang yang selalu mencari informasi mengenai produk yang diminatinya dan mencari informasi untuk mendukung sifat-sifat positif dari produk tersebut.

\subsection{Sikap}

Kotler dan Amstrong (2007) mengemukakan sikap adalah evaluasi, perasaan, dan kecenderungan yang konsisten atas suka atau tidak sukanya seseorang atas objek atau ide.

Menurut Schiffman, et.al (2007), struktur sikap terdiri atas sikap yang saling menunjang, yaitu :

1. Sikap Kognitif

Kognitif berkaitan dengan pikiran (otak) seseorang, apa yang dipikirkan konsumen. Sedangkan sikap kognitif ialah pengetahuan dan persepsi yang diperoleh melalui kombinasi dari pengalaman langsung dengan obyek sikap dan informasi terkait yang didapat dari berbagai sumber. Pengetahuan dan persepsi tersebut biasanya berbentuk kepercayaan (beliefs) artinya konsumen mempercayai bahwa suatu objek sikap memiliki atribut dan perilaku yang spesifik dan akan mengarahkan pada hasil yang spesifik. Menurut pendapat Mowen dan Minor (2002:312) kepercayaan adalah semua pengetahuan yang dimiliki oleh konsumen dan semua kesimpulan yang dibuat konsumen tentang objek, atribut dan manfaatnya. Dalam hal ini juga konsumen memiliki pengetahuan dan kesimpulan tentang objek, atribut, dan manfaat produk yang diinginkan dimana produk tersebut ditawarkan oleh dropshipper.

2. Sikap Afektif

Afektif berkaitan dengan perasaan, jadi sifatnya emosional dan wujudnya berupa perasaan senang, sedih, ceria, gembira dan sebagainya. Sedangkan sikap afektif ialah emosi atau perasaan terhadap suatu produk atau merek tertentu. Emosi dan perasaan ini sering dianggap bersifat sangat evaluatif yaitu mencakup penilaian seseorang terhadap obyek sikap secara langsung dan menyeluruh. Afektif mengungkapkan penilaian konsumen terhadap suatu produk apakah baik atau buruk, disukai atau tidak disukai. Sikap afektif disini juga mengungkapkan penilaian konsumen terhadap produk yang disukai atau tidak disukai dimana produk tersebut ditawarkan oleh dropshipper.

3. Sikap Konatif

Konatif berkaitan dengan tindakan. Sedangkan sikap konatif ialah kecenderungan seseorang untuk melaksanakan suatu tindakan dan perilaku dengan cara tertentu terhadap suatu obyek sikap. Sikap konatif dalam pemasaran penelitian konsumen 
lazimnya diperlakukan sebagai ekspresi niat konsumen untuk membeli atau menolak suatu produk yang ditawarkan oleh dropshipper.

\subsection{E-Commerce}

Istilah E-commerce sebenarnya dapat didefinisikan berdasar lima perspektif (Phan, 1998): (1) online purchasing perspective; (2) digital communications perspective; (3) service perspective; (4) business process perspective; dan (5) market of one perspective. Dengan demikian, pada hakikatnya dalam lingkup yang luas e-commerce bisa dikatakan ekuivalen atau sama dengan e-business (Turban, et al., 2000).

E-commerce adalah penyebaran, pembelian, penjualan, pemasaran barang dan jasa melalui sistem elektronik seperti internet, televisi, atau jaringan komputer lainnya. Ecommerce dapat melibatkan transfer dana elektronik, pertukaran data elektronik, sistem manajemen inventori otomatis, dan sistem pengumpulan data otomatis (Sunarto: 2009).

\subsection{Dropship}

Dropship adalah sebuah model bisnis yang melibatkan pihak ketiga (dropshipper) yang menjembatani hubungan antara pembeli dan produsen atau supplier barang. Sekilas peran dropshipper mirip sekali dengan reseller. Ia menjual barang dari supplier ke pembeli. Si dropshipper dapat menentukan harga jual yang berbeda dengan supplier. Selisih harga itulah yang menjadi keuntungan bagi dropshipper. Model bisnis dropship meminta supplier barang mengirimkan barang ke pembeli atas nama dropshipper. Seolah-olah dropshipper yang menjadi penjual pertama dari produk. Padahal, dropshipper hanya mempromosikan barang yang dimiliki supplier (Indra, 2020).

\subsection{Kerangka Konseptual Penelitian}

Berdasarkan rumusan masalah dan landasan teori di atas, maka kerangka konseptual dari penelitian ini dapat digambar secara ringkas sebagai berikut:

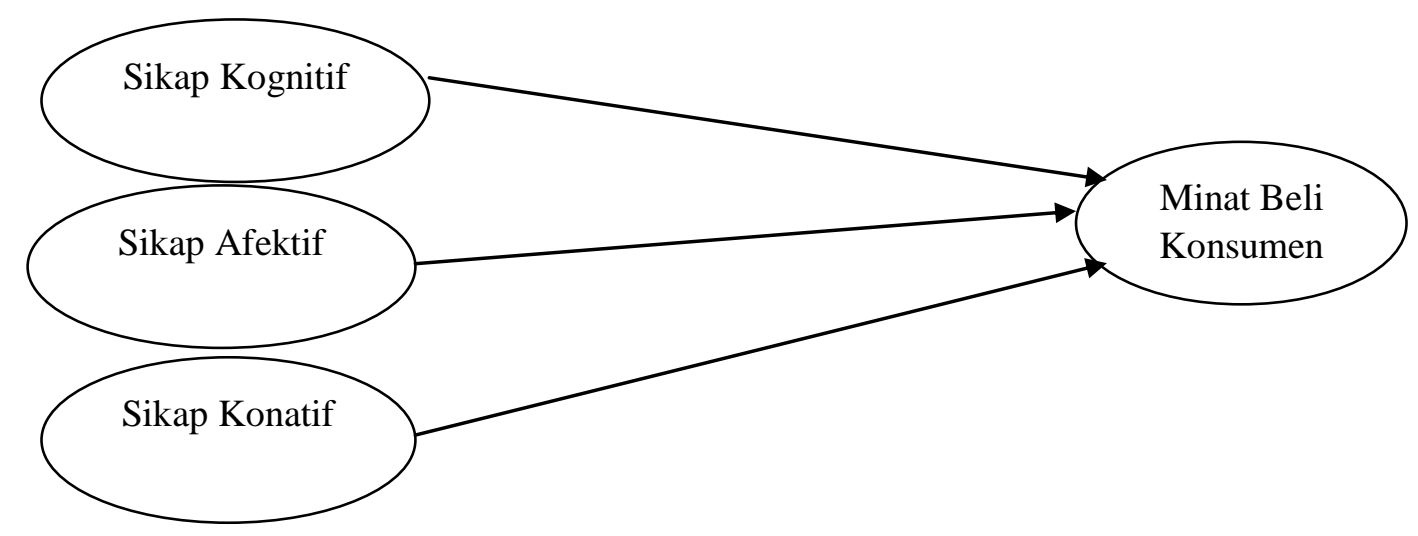

\section{METODOLOGI PENELITIAN}

\subsection{Populasi dan Sampel Penelitian}

Sugiyono (2016) mendefinisikan populasi sebagai wilayah generalisasi yang terdiri atas obyek/subyek yang mempunyai kuantitas dan karakteristik tertentu yang ditetapkan oleh peneliti untuk dipelajari dan kemudian ditarik kesimpulannya. Populasi dalam penelitian ini adalah individu/masyarakat NTB yang berminat untuk berbelanja online melalui dropshiper. Populasi dalam penelitian ini memiliki jumlah yang tidak diketahui, sehingga dalam menentukan sampelnya akan dijelaskan pada bagian selanjutnya. 
Sampel adalah bagian dari jumlah dan karakteristik yang dimiliki oleh populasi tersebut (Sugiyono, 2016). Roscoe dalam (Sekaran, 2006) memberikan pedoman penentuan jumlah sampel yaitu ukuran sampel harus 5-10 kali lebih besar dari jumlah variabel yang akan dianalisis dan ukuran sampel yang layak adalah di antara 30-500. Jumlah populasi dalam penelitian ini tidak diketahui jumlahnya secara pasti, maka dalam penelitian ini penentuan sampel untuk dijadikan responden diperoleh dari jumlah indikator setiap variabel dikali 10. Variabel sikap kognitif berjumlah 2 indikator $\times 10=20$, variabel sikap afektif berjumlah 1 indikator $\times 10=10$, variabel sikap konatif berjumlah $1 \times 10=10$, dan variabel minat beli berjumlah 4 indikator $\times 10=40$. Hasil perkalian dari seluruh indikator dijumlahkan sehingga diperoleh responden sebanyak 80 responden yang terdiri dari individu/masyarakat NTB yang berminat untuk berbelanja online melalui dropshiper. Jumlah 80 responden dianggap cukup karena telah memenuhi ukuran sampel yang layak.

Teknik penentuan sampel yang digunakan pada penelitian ini adalah nonprobability sampling dengan metode convenience sampling. Dengan metode convenience sampling, responden yang berhak mengisi kuesioner tergantung sepenuhnya kepada kemudahan penelitian. Dimana informasi atau data penelitian diperoleh dari anggota populasi yang dapat dengan mudah diakses oleh peneliti (Sekaran, 2006).

\subsection{Hasil Uji Validitas dan Reliabilitas}

Tabel 3.1 Hasil Uji Validitas Variabel

\begin{tabular}{|c|c|c|c|c|}
\hline No. & Pernyataan & r hitung & $\mathrm{r}$ tabel & Keterangan \\
\hline \multicolumn{5}{|c|}{ Sikap Kognitif } \\
\hline 1. & Saya mengetahui produk yang ditawarkan dropshipper & 0,778 & \multirow{4}{*}{0,30} & Valid \\
\hline 2. & $\begin{array}{l}\text { Saya mengetahui kualitas produk yang ditawarkan } \\
\text { dropshipper }\end{array}$ & 0,902 & & Valid \\
\hline 3. & $\begin{array}{l}\text { Saya mengetahui manfaat produk yang ditawarkan } \\
\text { dropshipper }\end{array}$ & 0,812 & & Valid \\
\hline 4. & $\begin{array}{l}\text { Membeli online pada dropshipper merupakan ide yang } \\
\text { baik }\end{array}$ & 0,805 & & Valid \\
\hline \multicolumn{5}{|c|}{ Sikap Afektif } \\
\hline 5. & Saya menyukai situs belanja online milik dropshipper & 0,795 & \multirow{3}{*}{0,30} & Valid \\
\hline 6. & $\begin{array}{l}\text { Saya memiliki kesan positif dalam membeli produk } \\
\text { online melalui dropshipper }\end{array}$ & 0,913 & & Valid \\
\hline 7. & $\begin{array}{l}\text { Saya puas terhadap pelayanan dropshipper di situs } \\
\text { online }\end{array}$ & 0,821 & & Valid \\
\hline \multicolumn{5}{|c|}{ Sikap Konatif } \\
\hline 8. & $\begin{array}{l}\text { Membeli online pada dropshipper lebih baik daripada } \\
\text { belanja offline }\end{array}$ & 0,919 & \multirow[t]{2}{*}{0,30} & Valid \\
\hline 9. & Membeli online adalah hal menyenangkan & 0,811 & & Valid \\
\hline \multicolumn{5}{|c|}{ Minat Beli } \\
\hline 10. & $\begin{array}{l}\text { Saya berminat membeli produk secara online melalui } \\
\text { dropshipper }\end{array}$ & 0,876 & \multirow{4}{*}{0,30} & Valid \\
\hline 11. & $\begin{array}{l}\text { Saya berminat merekomendasikan kerabat untuk } \\
\text { berbelanja online melalui dropshipper }\end{array}$ & 0,943 & & Valid \\
\hline 12. & $\begin{array}{l}\text { Saya akan menjadikan dropshipper sebagai pilihan } \\
\text { pertama dalam berbelanja online }\end{array}$ & 0,564 & & Valid \\
\hline 13. & $\begin{array}{l}\text { Saya akan selalu mencari informasi terbaru melalui } \\
\text { dropshipper mengenai produk yang diinginkan }\end{array}$ & 0,799 & & Valid \\
\hline
\end{tabular}

Sumber : data Primer diolah 2021 
Tabel 3.2. Hasil Uji Reliabilitas

\begin{tabular}{|l|c|c|}
\hline \multicolumn{1}{|c|}{ Variabel } & Cronbach's Alpha & Tingkat Keandalan \\
\hline Sikap Kognitif & 0,843 & Sangat andal \\
\hline Sikap Afektif & 0,778 & Andal \\
\hline Sikap Konatif & 0,645 & Andal \\
\hline Minat Beli & 0,888 & Sangat andal \\
\hline
\end{tabular}

Sumber : data Primer diolah 2021

\subsection{Persamaan Regresi}

$$
Y=0.258+0.134\left(X_{1}\right)+0.403\left(X_{2}\right)+0.382\left(X_{3}\right)+e
$$

$\mathrm{Y}$ adalah Minat Beli Online, $\left(\mathrm{X}_{1}\right)$ adalah Sikap Kognitif, $\left(\mathrm{X}_{2}\right)$ adalah Sikap Afektif, $\left(\mathrm{X}_{3}\right)$ adalah Sikap Konatif. Dari persamaan diatas, dapat dianalisis beberapa hal, antara lain:

a). Nilai kostanta (nilai tetap) atau nilai Minat Beli sebesar 0.258 bermakna bahwa apabila variabel bebas (Sikap Kognitif, Sikap Afektif, dan Sikap Konatif di asumsikan nilainya tetap maka akan terdapat nilai kostanta sebesar 0.258 atau tetap. Jika nilai kostantanya bertambah maka nilai variabel bebas akan memberikan perubahan positif secara signifikan terhadap perubahan pada variabel bebas.

b). Koefisien regresi variabel sikap kognitif (X1) sebesar 0,134; bermakna bahwa jika terjadi peningkatan pada variabel sikap kognitif sebesar $100 \%$ maka akan terjadi peningkatan juga pada minat beli online sebesar 0,13\% dengan asumsi variabel Sikap Afektif dan Konatif tetap atau tidak mengalami perubahan.

c). Koefisien regresi variabel sikap afektif (X2) sebesar 0,403; bermakna bahwa jika terjadi peningkatan pada variabel sikap afektif sebesar $100 \%$ maka akan terjadi peningkatan juga pada minat beli online sebesar 0,40\% dengan asumsi variabel Sikap Kognitif dan Konatif tetap atau tidak mengalami perubahan.

d). Koefisien regresi variabel sikap konatif (X3) sebesar 0,382; bermakna bahwa jika terjadi peningkatan pada variabel sikap konatif sebesar 100\% maka akan terjadi peningkatan juga pada minat beli online sebesar 0,38\% dengan asumsi variabel Sikap Afektif dan Kognitif tetap atau tidak mengalami perubahan.

\subsection{Hasil Uji Statistik t (Parsial)}

Tabel 4.3. Hasil Uji Koefisien $t_{\text {tes }}$ Regresi secara parsial

\begin{tabular}{|l|l|l|l|}
\hline Model & $\mathbf{t}_{\text {hitung }}$ & Sig & Ket \\
\hline Sikap Kognitif (X1) & 1.130 & 0,263 & Tidak Signifikan \\
\hline Sikap Afektif (X2) & 2.913 & 0,005 & Signifikan \\
\hline Sikap Konatif (X3) & 3.995 & 0,000 & Signifikan \\
\hline
\end{tabular}

a. Dependent Variabel: Minat Beli Online

\section{Pengaruh Sikap Kognitif Terhadap Minat Beli Online}

Dari tabel 4.11 terlihat bahwa hasil pengujian hipotesis pengaruh sikap kognitif terhadap minat beli online menunjukkan nilai $t_{\text {hitung }}$ sebesar $\mathbf{1 . 1 3 0}$ yang lebih besar dari nilai $t_{\text {tabel }}$ dengan a $0.05=\mathbf{1 . 9 9 0}$ atau nilai signifikansi sebesar 0,263 lebih dari 0,05 . Hasil ini berarti bahwa hipotesis observasi (Ho) diterima dan menolak hipotesis alternatif (Ha). Dengan demikian dapat disimpulkan bahwa sikap kognitif berpengaruh secara positif namun tidak secara signifikan mempengaruhi minat beli online masyarakat Nusa Tenggara Barat.

\section{Pengaruh Sikap Afektif terhadap Minat Beli Online}

Dari tabel 4.11 terlihat bahwa hasil pengujian hipotesis pengaruh sikap afektif terhadap minat beli online menunjukkan nilai thitung sebesar 2.913 yang lebih besar 
dari nilai $t_{\text {tabel }}$ dengan a $0.05=\mathbf{1 . 9 9 0}$ atau nilai signifikansi sebesar 0,005 kurang dari 0,05. Kenyataan ini berarti bahwa hipotesis observasi (Ho) ditolak dan menerima hipotesis alternatif $(\mathrm{Ha})$. Dengan demikian dapat disimpulkan bahwa sikap afektif berpengaruh secara positif dan signifikan terhadap Minat Beli Online Masyarakat Nusa Tenggara Barat.

Kedua variabel ini saling terkait dan searah artinya ada hubungan positif antara variabel sikap afektif terhadap minat beli online. Semakin baik emosional perasaan terhadap produk yang ditawarkan oleh dropshipper maka akan tinggi tingkat minat beli online masyarakat Nusa Tenggara Barat.

\section{Pengaruh Sikap Konatif Terhadap Minat Beli Online}

Dari tabel 4.11 terlihat bahwa hasil pengujian hipotesis pengaruh Sikap Konatif terhadap minat beli online menunjukkan nilai thitung sebesar 3.995 yang lebih besar dari nilai $t_{\text {tabel }}$ dengan a $0.05=\mathbf{1 . 9 9 0}$ atau nilai signifikansi sebesar 0,000 kurang dari 0,05 . Kenyataan ini berarti bahwa hipotesis observasi (Ho) ditolak dan menerima hipotesis alternatif (Ha). Dengan demikian dapat disimpulkan bahwa Sikap Konatif berpengaruh secara positif dan signifikan terhadap Minat Beli Online Masyarakat Nusa Tenggara Barat.

Kedua variabel ini saling terkait dan searah artinya ada hubungan positif antara variabel Sikap Konatif terhadap minat beli online. Semakin baik sikap dalam bentuk ekspresi niat untuk membeli suatu produk yang ditawarkan maka semakin tinggi minat beli online masyarakat Nusa Tenggara Barat.

\subsection{Uji Koefisien Determinasi $\left(\mathbf{R}^{2}\right)$}

Tabel 4.4. Hasil Uji Koefisien Determinasi $\left(\mathbf{R}^{2}\right)$

Model Summaryb

\begin{tabular}{|c|c|c|c|c|c|}
\hline Model & $R$ & R Square & $\begin{array}{l}\text { Adjusted } \\
\text { Square }\end{array}$ & & $\begin{array}{l}\text { Std. Error of the } \\
\text { Estimate }\end{array}$ \\
\hline 1 & $.858^{a}$ & .736 & & .725 & .46814 \\
\hline
\end{tabular}

a. Predictors: (Constant), Sikap_Konatif, Sikap_Kognitif, Sikap_Afektif

b. Dependent Variable: Minat Beli_Y

Hasil pengolahan dengan menggunakan program SPSS menunjukkan bahwa $R^{2}$ Square (koefisien determinasi) untuk model ini adalah nilai $\mathrm{RxR}=\mathrm{R}^{2}(0,858 \times 0,858=0,736)$. Jadi 0,736 artinya $74,0 \%$ minat beli online dapat dijelaskan oleh variabel sikap kognitif, afektif dan konatif. Sedangkan sisanya 26,0\% dijelaskan oleh faktor lainnya yang tidak di jelaskan dalam penelitian ini.

\section{HASIL DAN PEMBAHASAN}

\subsection{Pengaruh Sikap Kognitif terhadap minat beli online melalui Dropshipper pada Media E-Commerce}

Pada penelitian ini sikap kognitif adalah sebagai variabel bebas dan minat beli online sebagai variabel terikat dengan menggunakan indikator pengetahuan dan persepsi yang di adopsi dari Marsella (2017), Mantala \& Suasana (2019) telah disesuaikan.

Pada hipotesis penelitian menyatakan bahwa sikap kognitif berpengaruh signifikan terhadap minat beli. Hasil penelitian menunjukkan bahwa sikap kognitif berpengaruh tidak signifikan terhadap minat beli online melalui dropshipper pada media e-commerce. Sikap kognitif terhadap minat beli memiliki pengaruh namun tidak secara signifikan. Hal ini berarti bahwa responden dalam sikap terhadap minat beli untuk 
melakukan pembelian produk secara online pada media e-commerce tidak menunjukkan pengaruh yang berarti jika melalui dropshipper.

Dari hasil temuan penelitian ini bahwa sikap kognitifnya berpengaruh tidak signifikan, hal ini bertolak belakang dengan hipotesis penelitian, namun hasil ini akan menjadi pertimbangan gap teori dalam penelitian lebih lanjut untuk mengkaji kembali pengaruh sikap kognitif terhadap minat beli. Hasil penelitian ini memiliki kesamaan dengan temuan penelitian yang dilakukan oleh Kiptiah (2015) bahwa variabel sikap kognitif berpengaruh tidak signifikan terhadap minat beli.

\subsection{Pengaruh Sikap Afektif terhadap minat beli online melalui Dropshipper pada Media E-Commerce}

Pada penelitian ini sikap afektif dapat mempengaruhi minat beli konsumen melalui dropshipper. Dalam penelitian ini, sebagian besar responden merasa senang dengan lebih setuju menyukai belanja online milik dropshipper karena telah memiliki kesan positif dalam membeli produk melalui dropshipper. Hal ini juga responden menunjukkan rasa puas terhadap pelayanan dropshipper pada media e-commerce. Dari hal ini mempengaruhi minat beli yaitu responden berminat membeli produk secara online melalui dropshipper, dimana minat ini dilakukan oleh responden dengan merekomendasi kerabat yang akan menjadikan dropshipper sebagai pilihan pertama dalam belanja online.

Hasil penelitian ini menunjukkan bahwa sikap afektif berpengaruh signifikan terhadap minat beli online melalui dropshipper pada media e-commerce. Hasil ini didukung oleh penelitian yang dilakukan oleh Aqsa (2018) bahwa sikap afektif memiliki pengaruh yang signifikan terhadap minat membeli secara online. Secara umum dapat dikatakan bahwa semakin baik sikap dirasakannya, maka semakin kuat minat konsumen tersebut untuk melaksanakan pembelian yang dimaksud. Hasil penelitian ini juga didukung oleh penelitian Sreen et al., (2018) Ansyah dan Abror (2019) bahwa sikap memiliki pengaruh terhadap minat beli konsumen.

\subsection{Pengaruh Sikap Konatif terhadap minat beli online melalui Dropshipper pada Media E-Commerce}

Hasil penelitian ini menunjukkan bahwa sikap konatif berpengaruh signifikan terhadap minat beli online melalui dropshipper. Pengaruh ini terlihat yang ditunjukkan oleh responden yaitu merasa senang ketika berbelanja online pada dropshipper lebih baik daripada belanja offline, membeli online melalui dropshipper adalah hal menyenangkan. Dari hal ini mempengaruhi minat responden seperti berminat membeli produk secara online melalui dropshipper, berminat merekomendasikan kerabat untuk berbelanja online melalui dropshipper, akan menjadikan dropshipper sebagai pilihan pertama dalam berbelanja online, dan akan selalu mencari informasi terbaru melalui dropshipper mengenai produk yang diinginkan.

Sikap konatif dalam penelitian ini adalah berkaitan dengan tindakan atas produk yang diinginkan atau dipilih konsumen dan dapat menyenangkan bagi konsumen.

Hasil penelitian secara statistik bahwa variabel sikap konatif berpengaruh signifikan terhadap minat beli. Hasil penelitian ini sesuai dengan hasil penelitian yang dilakukan oleh Ardiansyah (2016) bahwa sikap berpengaruh dominan terhadap minat beli online.

Minat beli (willingness to buy) merupakan bagian dari sikap perilaku dalam sikap mengkonsumsi. Minat beli konsumen adalah tahap dimana konsumen membentuk pilihan mereka diantara beberapa merek yang tergabung dalam perangkat pilihan, kemudian pada akhirnya melakukan suatu pembelian pada suatu altenatif yang paling disukainya atau 
proses yang dilalui konsumen untuk membeli suatu barang atau jasa yang didasari oleh bermacam pertimbangan (Pramono, et.al. 2012).

\section{KESIMPULAN DAN SARAN}

\subsection{Kesimpulan}

Berdasarkan pada hasil penelitian dan hipotesis yang menunjukkan adanya pengaruh variabel sikap terhadap minat beli online masyarakat NTB melalui Dropshipper pada Media E-Commerce, sebagai berikut :

1). Variabel Sikap Kognitif berpengaruh positif dan tidak signifikan terhadap minat beli online melalui Dropshipper pada Media E-Commerce. Sikap Kognitif ini berkaitan dengan pengetahuan dan persepsi terhadap atribut dan manfaat pada produk. Indikatorindikator ini belum dapat mempengaruhi minat beli online melalui dropshipper masyarakat NTB.

2). Variabel Sikap Afektif berpengaruh positif dan signifikan terhadap minat beli online melalui Dropshipper pada Media E-Commerce. Indikator-indikator yang digunakan Sikap Afektif yaitu kesukaan, kesan positif dan kepuasaan. Indikator-indikator ini dapat meningkatkan pengaruh terhadap minat beli online masyarakat NTB. Semakin baik sikap afektif yang dimiliki maka semakin tinggi minat beli online masyarakat NTB melalui dropshipper pada media E-Commerce.

3). Variabel Sikap Konatif berpengaruh positif dan signifikan terhadap minat beli online melalui Dropshipper pada Media E-Commerce. Adapun indikator Sikap Konatif yaitu tindakan dan menyenangkan. Indikator-indikator ini dapat meningkatkan pengaruh terhadap minat beli online masyarakat NTB. Semakin baik sikap konatif yang dimiliki maka semakin tinggi minat beli online masyarakat NTB melalui dropshipper pada media E-Commerce.

\subsection{Saran}

A. Implikasi Manajerial, Bagi pelaku usaha online, sikap afektif dan sikap konatif dalam minat beli melalui dropshipper pada media e-commerce menjadi hal yang sangat penting, karena jika sikap ini dapat ditingktkan menjadi sangat baik maka konsumen akan meningkatkan minat beli terhadap media e-commercce melalui dropshipper. Selain itu, dalam belanja pada media E-commerce, dimana penjualnya atau sebagai dropshipper berasal dari banyak pihak, pelaku bisnis perlu tetap memperhatikan dan menjaga kepercayaan konsumen. Hal ini dapat dilakukan pelaku bisnis online dengan meningkatkan pelayanan sesuai ekspetasi konsumen. Dengan adanya atensi dari pelaku bisnis online, tentunya akan membuat konsumen merasa lebih percaya untuk mengunjungi kembali situs belanja online pada media E-Commerce tersebut.

B. Untuk peneliti mendatang, jika melakukan penelitian yang serupa, diharapkan dapat menambah variabel-variabel lain seperti Variabel Kepercayaan, persepsi harga, pesan iklan online dan kemudahan dalam transaksi online yang dapat mempengaruhi dalam meningkatkan minat beli. Selanjtnya dalam pengembangan penelitian lebih lanjut, penambahan jumlah sampel, karakteristik sampel, dan penyebaran kuesioner harus dipertimbangkan mengingat dalam penelitian ini sampel masih sedikit di dominasi oleh perempuan dan penyebaran kuesioner hanya terpusat di satu provinsi tertentu saja. 


\section{DAFTAR PUSTAKA}

Ajzen, I. \& Fishbein, M. 1975. Understanding Attitudes and Predicting Social Behavior. Prentice-hall, Englewood Cliffs, NJ

Azwar , 2013. Sikap manusia: teori dan pengukurannya. Yogyakarta: Pustaka pelajar

Ardiansyah, R., (2016), Analisis Faktor-faktor yang mempengaruhi Minat Beli Online Shop

Konsumen. Jurnal Manajemen Pemasaran Universitas Islam Indonesia.

Aqsa, M., Pengaruh Iklan Online Terhadap Sikap Dan Minat Beli Konsumen Secara Online Di Kota Palopo (Survei pada Pengguna Internet di Kota Palopo). Jurnal Ekonomi, Vol 03, no 1: pp82-352

Ansyah, F. \& Abror. (2019). Pengaruh Persepsi Resioko dan Kepercayaan Pada Vendor Terhadap Minat Beli yang DImediasi oleh SIkap Konsumen Toko Online Lazada di Kota Padang. Jurnal Kajian Manajemen dan Wirausaha. I (1) : 46-58.

Ansyah, F. \& Abror. (2019). Pengaruh Persepsi Resioko dan Kepercayaan Pada Vendor Terhadap Minat Beli yang DImediasi oleh SIkap Konsumen Toko Online Lazada di Kota Padang. Jurnal Kajian Manajemen dan Wirausaha. I (1) : 46-58.

Barkatullah, A.A. \& Prasetyo, T. (2005), Bisnis E-Commerce: Studi Sistem Kemanan dan Hukum di Indonesia, Yogyakarta: Pustaka Belajar.

Binalay, A.G., Mandey, S.L. \& Mintardjo, C.M.O. (2016), Pengaruh Sikap. Norma Subjektif dan Motivasi Terhadap Minat Beli Secara Online Pada Mahasiswa Fakultas Ekonomi dan Bisnis di Manado, Jurnal EMBA, VI (1) : 395-406.

Dewi dan Ardani. (2016). Pengaruh Sikap, Norma Subjektif terhadap Niat Beli Ulang Produk Fashion Via Online di Kota Denpasar. Jurnal Universitas Udayana. Vol. 5 No. 1, hal 650-674.

Ferdinand, A. (2006),Metode Penelitian Manajemen, Semarang: BP UNDIP.

Kotler, P. (2008),Manajemen Pemasaran Edisi 12 Jilid 2, Jakarta: Indeks.

Kotler, P. \& Armstrong, G. (2008), Prinsip-prinsip Pemasaran Edisi Ke-12 Jilid 1, Jakarta: Erlangga.

Kotler, Philip \& Keller, K.L. (2009), Manajemen Pemasaran, Jakarta: Erlangga.

Kiptiah, M., (2015) Respon Kognitif, Afektif dan Konatif Pegawai Fakultas Syariah dan Hukum Syarif Hidayatullah Jakarta Terhadap Minat Berasuransi Syariah. Jurnal Ekonomi Syariah Universitas Islam Negeri Jakarta.

Lim, S., Ilies, R., Koopman, J., Christoforou, P., \& Arvey, R.D. 2016. Emotional Mechanisms Linking Incivility at Work to Aggression and Withdrawal at Home: An Experience-Sampling Study, Journal of Management. Vol. 1, pp. 1-21.

Mowen, John dan Michael Minor. 2002. Perilaku Konsumen. Jakarta : Erlangga

Pramono, Suyono, A.G., Sukmawati, S., 2012.Pertimbangan Dalam Membeli Produk Barang Maupun Jasa. Intidayu Press. Jakarta.

Putra, Putu Eka Yusdiawan dan Ida Bagus Sudiksa. (2016). Peran Sikap Dalam Memediasi Hubungan Antara Harga Dengan Niat Beli Smartphone Merek Samsung. E-Jurnal Manajemen Unud, Vol. 5, No. 10, pp6762-6794

Rossiter, John R.\& Larry Percy. (1997),Advertising And Promotion Management, Mc- GrawHill Inc. Alright All Reserved Printed In The United States Of America.

Sreen, N., Purbey, S. \& Sadarangani, P. (2018). Impact of Culture, Behavior and Gender on Green Purchase Intention. Urnal of Retailing and Consumer Services. 41 : 177-189.

Solimun. (2005),Analisis Multivariat Structural Equation Modeling (SEM), Jakarta: Gramedia Pustaka Utama.

Sekaran, U. (2006), Metodologi Penelitian Bisnis (Terjemahan), Jakarta: Salemba Empat. 
Sugiyono. (2016), Metode Penelitian Kuantitatif, Kualitatif, dan RED, Bandung: Penerbit Alfabeta.

Suyanto, M.(2003), Strategi Periklanan Pada E-Commerce Perusahaan Top Dunia, Yogyakarta: Andi.

Schiffman, Leon, G., dan Leslie, L., Kanuk. 2007. Consumer Behavior 9th ed., Pearson Prentice Hall., New Jersey.

Schiffman, Leon, G., dan Leslie, L., Kanuk. Consumer Behavior. 10th edition. 2010. New Jersey: Pearson Prentice Hall.

Sunarto, A., (2009), Seluk Beluk E-Commerce, Graha Ilmu, Yogyakarta.

Sekaran, U. (2006), Metodologi Penelitian Bisnis (Terjemahan), Jakarta: Salemba Empat.

Sugiyono. (2016), Metode Penelitian Kuantitatif, Kualitatif, dan RED, Bandung: Penerbit Alfabeta.

Turban, Efraim, et al. 2000. Electronic Commerce a Managerial Perspective. New Jersey : Pearson Education International.

Wattimena, Ollidia Yoanna. 2015. Analisis Pengaruh Sikap Konsumen Terhadap Keputusan Memilih Jasa Asuransi Kesehatan XYZ Di Palembang. STIE MDP Palembang.

Wardhani, M.M.K., (2009), Analsisis Pengaruh Sikap Konsumen Terhadap Minat Beli Produk Pemutih Wajah Pond's Flawless White Dalam Iklan Versi Story Line Di Televisi. Jurnal Manajemen Pemasaran Universitas Sanata Dharma Yogyakarta. 